\title{
The Germ of the Prinzipalbogen Concept in Bartel Ranisch
}

\author{
Elena Pliego de Andrés ${ }^{1}$
}

Published online: 19 May 2017

(C) Kim Williams Books, Turin 2017

\begin{abstract}
The Prinzipalbogen concept, as it has been described in nineteenth century technical literature, seems to be a fundamental tool in the design of Gothic vaults in the Central European area. We will analyze Bartel Ranisch's contribution to this concept by his text Beschreibung aller Kirchengebäude der Stadt Dantzig (1695), focused on the description of the geometrical procedure employed in the design of the arches of Gothic vaults with means of a common arch that he calls Haupt-Bogen or Quadrant. We have developed a complete study of Ranisch's descriptions of all vaults, what, despite the frequent references to this text, especially by German authors during the nineteenth and twentieth centuries, had never been carried out before. In this paper we will show some conclusions about the geometrical procedures described by Ranisch and its interpretation during construction history.
\end{abstract}

Keywords Vaults · Late Gothic $\cdot$ Prinzipalbogen · Danzig · Bartel

Ranisch

\section{Introduction}

The Prinzipalbogen concept, described in nineteenth-century technical literature as the procedure in which the arches of a Gothic vault are all drawn with the same radius, seems to have been a fundamental tool in the design of Gothic vaults in the Central European area. In the present paper we want to go further by analyzing its origin and its different interpretations through construction history. Its germ, already present in the drawings of previous treatises (the fifteenth-century Musterbücher and

Elena Pliego de Andrés

epliego@solnetcs.com

1 c/Príncipe de Vergara 210, esc. A, 9B, 28002 Madrid, Spain 
Steinmetzbücher), ${ }^{1}$ is to be found, according to Norbert Nußbaum (Nußbaum and Lepsky 1999) for the first time in the technical literature in Bartel Ranisch's Beschreibung aller Kirchengebäude der Stadt Dantzig (1695). This publication includes the description of the fourteen churches of Danzig (Gdansk, Poland) as well as the drawings of their plans and elevations. These are preserved thanks to this text, as the great part of these churches, constructed between the thirteenth and the fifteenth centuries (the vaults belong to late Gothic period, having been built after 1465), were destroyed or partially damaged during World War II.

But the real interest of Bartel Ranisch himself is focused on the geometrical procedures employed in the design of the vaults by means of the Prinzipalbogen construction, and, as a consequence, the text consists basically of a list of the vaults of the different churches and the accurate description of the corresponding geometrical design in plan and elevation. Ranisch's description of the geometry of the ribs, whose arches are all drawn with the same radius, equal half the diagonal in plan of the vault, was picked up later on by other authors, including Friedrich Hoffstadt (1840-63) and Georg Gottlob Ungewitter (1859-64) in the nineteenth century and Carl Anton Meckel (1933) in the twentieth.

Bartel Ranisch (b. 1648- d. 1702), son of a mason and master mason himself, was responsible for the construction of several buildings in Danzig, erected in the Baroque style proper to this period. He was also involved in the reconstruction of Danzig's Gothic churches, which could be the reason for his admiration for the Gothic vaults long before the renewal of interest in the Gothic that took place in the nineteenth century (Kaplan 1974).

The principal goal of this present paper is to analyze Bartel Ranisch's Beschreibung aller Kirchengebäude der Stadt Dantzig and to enhance an awareness of his contribution to the Prinzipalbogen concept in the history of the design and construction of the late Gothic vaults.

\section{The Term Prinzipalbogen in Beschreibung aller Kirchengebäude der Stadt Dantzig}

Although the Prinzipalbogen concept is already present in Ranisch's text, the term 'Prinzipalbogen' does not appear literally in the text but once (Ranisch 1695, p. 12); Ranisch uses Principal, Haupt-Bogen, a term that has the same meaning, Haupt-Circkel or Quadrant, but these terms were later transmitted as 'Prinzipalbogen'.

In Ranisch's text we find also other singular terms, such as Quadrant, Reigen, Bockverstellung, Kussen-Gewölbe, Steuffen, now out of use in the German language, leading to some difficulties in interpreting the text and translating it into other languages. This could be an interesting line of future research, but will not be discussed here.

\footnotetext{
1 Sketchbooks and drawing collections exploring the different possibilities in plan of the arches layout in late Gothic vaults. For more detail about late Gothic vault tracing in primary sources see (Rabasa-Díaz et al. 2015).
} 


\section{The Geometry of the Vaults Described by Bartel Ranisch}

Bartel Ranisch's text includes the description of fourteen churches constructed before 1695 within the walls of the city of Danzig. These complete descriptions include a brief reference to the construction history, based on the chronicle of Curicke (1686), accompanied by drawings of the plans and elevations. The most important part of the text is the geometrical description of the tracing of the arches of each of the forty-two vaults in seven of these fourteen churches, which had not been described before (Fig. 1).

Ranisch does not provide any information about the origin of his theory about the geometry of the ribs; we do not know if he did measurements of the vaults or if he based his drawings on previous documentation.

According to the description of the tracing of these vaults, the curvature of all arches would have been defined by the theoretical semi-circle traced over the diagonal of the vault. However, the implementation of this method, possibly deduced from the drawings of earlier treatises (the Musterbücher and Steinmetzbücher mentioned earlier) was described during the nineteenth century in a slightly different way: the radius of this theoretical arch would not correspond to the diagonal of the vault but to a fragmented path across the different arches over the longest way, starting in a corner of the springing and ending in the center.

In the development of this present research, all forty-two vaults described in Bartel Ranisch's work have been redrawn in plan and each of the different arches have been carefully analyzed. As a first conclusion, it can be stated that not all the descriptions follow exactly the same geometrical procedure: although in all cases the Prinzipalbogen is traced along the diagonal of the vault and used to define the curvature of all arches, the height of the intersections of the arches is found in different ways.

In what follows I will analyze the most significant vaults, ranging from the simplest to the more complex: from the vaults over the altar in St. Catarinen to the vaults over the nave in the convent church of St. Trinitatis, which are cylindrical, and the asymmetrical cloister vaults in the Dominicanerkirche. As a result of that analysis we can state the following points:

- The elevation of the intersections of the different arches is not determined in all cases by the horizontal distance to the center of the vault, as it has been described in the nineteenth century by Hoffstadt (1840-63) and Ungewitter (1859-64), but this horizontal distance is carried in many cases to the elevation directly to the arch or Quadrant, the Prinzipalbogen, instead of to the horizontal base of this arch (Fig. 5, distance ad). As a consequence, the intersections of the different arches are not always situated on a theoretical spherical or cylindrical surface, as was stated later on.

- The arches have no vertical tangent at the springing.

- The contour arches in most cases are traced by the same procedure.

As mentioned, the descriptions of the geometrical method to determine the height of the intersections of the arches vary throughout the text, so we will try to put 
St. Marienkirche

$\longmapsto 1,130$ feet
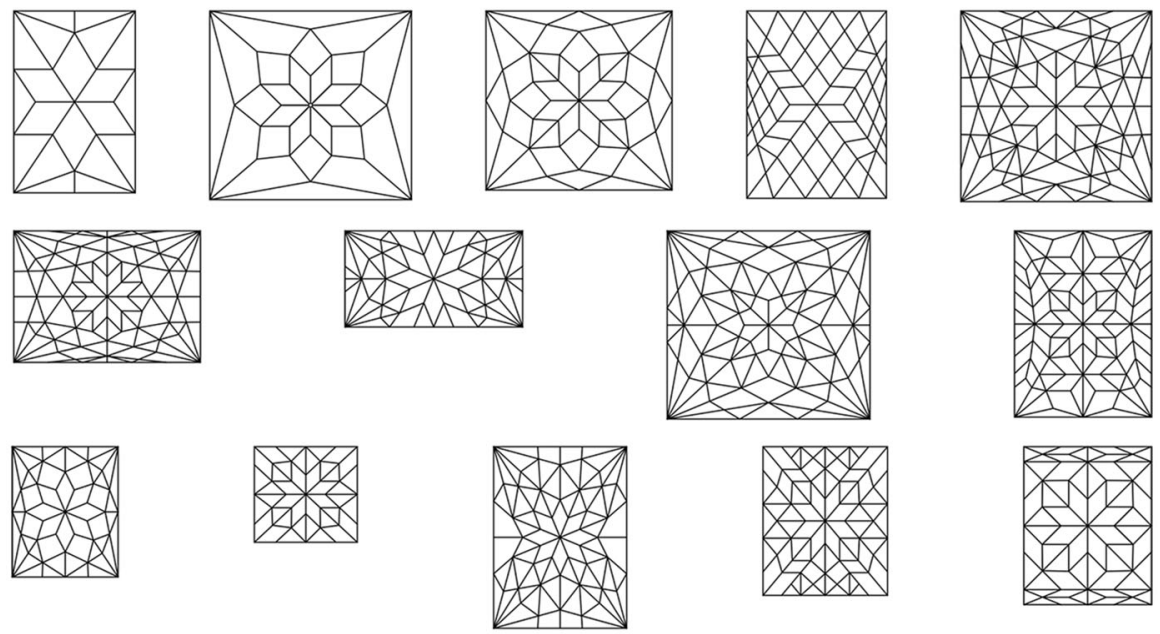

St. Johannes

St. Brigitten
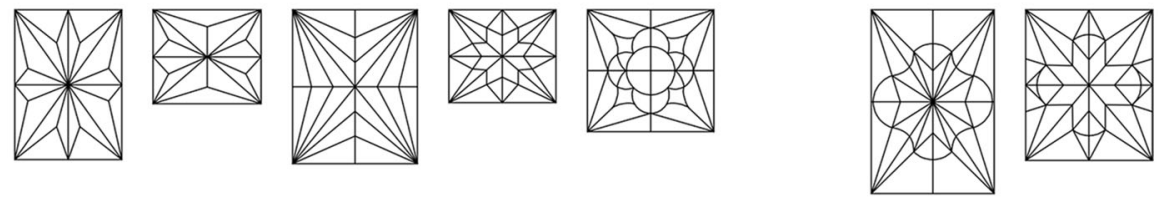

\section{St. Catarinen}
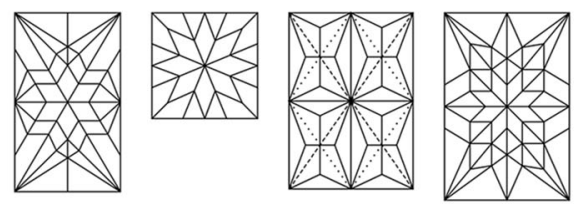

\section{St. Peter und Pauly}
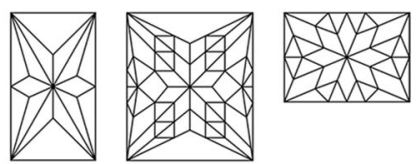

\section{Dominicanerkirche}
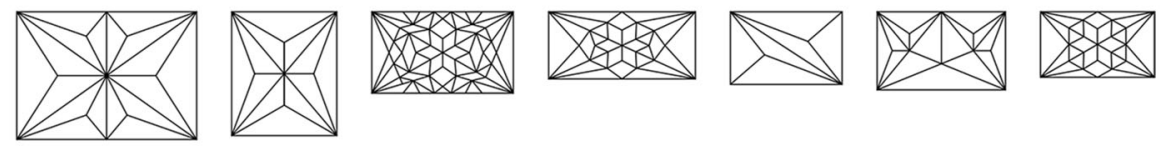

\section{St. Trinitatis}
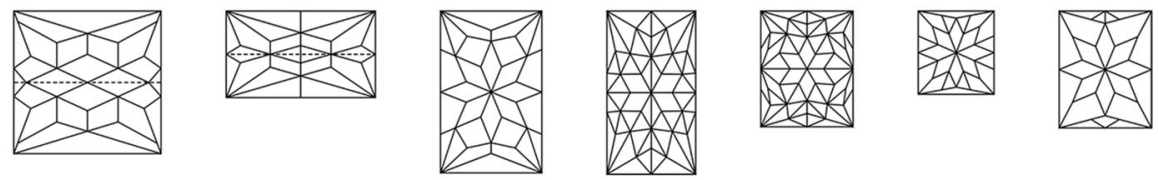

Fig. 1 Plan of all vaults in Beschreibung aller Kirchengebäude der Stadt Danzig. Image: author 
ourselves in Ranisch's shoes to understand the reason for this and to arrive at some explanations for this lack of uniformity in the text and in the drawings of the elevations. The fact that most of these vaults are not original, have been reconstructed following the destruction that took place during the second world war, makes this research undoubtedly more difficult, since it is not possible to compare Ranisch's drawings to the constructed buildings as they originally existed.

I will introduce now four examples of vaults with a very detailed geometrical analysis of the drawings of the elevations of the arches that I have selected from the forty-two vaults described by Ranisch in order to show that the Prinzipalbogen method is not a unique one.

\section{The Vaults Over the Altar in St. Catarinen}

The first thing to be noted about this vault is that there is not an exact correspondence between Ranisch's plan drawing and the photograph of the current vault (Fig. 2). Besides other changes that could have happened during its history, this church was completely rebuilt after the damages suffered during the second world war. However, according to the information that we have, it was reconstructed following the initial pattern.

Figure 3 shows a page from the original text by Ranisch. Here I provide a transcription. Some of the Gothic characters in which the original text is written, have been changed, in order to make it easier to read. Also, I've tried to simplify the punctuation changing the character / for commas, but I've tried to maintain as much as possible the original text and punctuation. In the original text Ranisch uses Latin characters for Latin words, such as Quadranten or Punct, what I've maintained in the transcription.
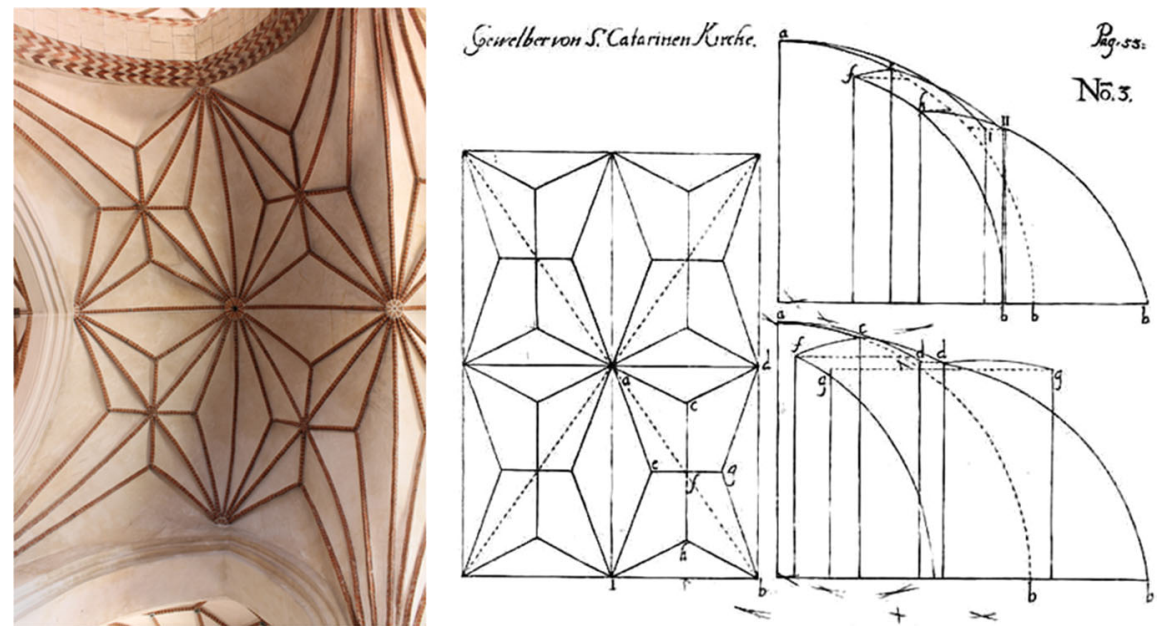

Fig. 2 Vaults over the altar in St. Catarinen. Left Photo: author (2014); Right plan drawing and elevation by Bartel Ranisch (1695: 53) 
Fig. 3 Description of the vaults over the altar in St. Catarinen by Bartel Ranisch (1695: 53, 54)
Das L. Eapitel.

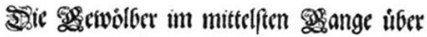
ocm grolien aitar.

Num. 111.

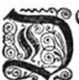

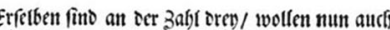

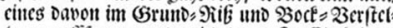
lung aufificken / uno wiro Der erfte Eircleel bes

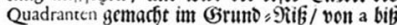
b. פan nelsme oemnact) Die W̧eite von a bifi b, uno mas dfe cinen blimben Quadranten davon. Shernact nimmt man

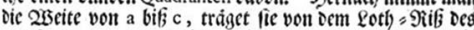
Quadranten a, uno machet nach ier Weite auch sincu $Q$ oth)

$$
\mathfrak{D}
$$

54 Das LI. Capitel.

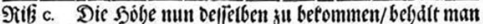

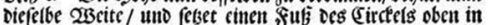
Den Quadranten a. Lino wo er im Quadrant- Circtel puncti-

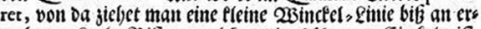

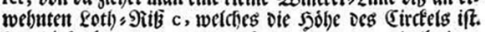
2us defen bet)ocn Puncten macfet man nun unterbalb sinen Rreul:-Scfinitt / wefcbes Dag Centrum ier 3 uge a, c, ift / ferner verfăbret man mit oer weite vont $\mathrm{c}$, bib̧ $\mathrm{d}$, tráget fie von oem Qotbrif $c$, $a b$ uno macket abermabl cinc Qotl)=Sinie aufiwerts. Die foobe oerfelben mun zu erfabren/ nimmet

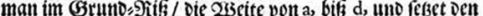
einen Su ander Punct Des (Circels bemerctet wiro/ in oem blinbelt

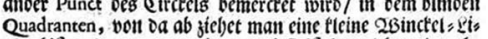

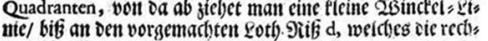

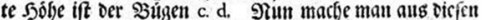

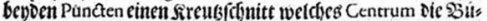
ge c, d, giebet / Darnach nimt man die Mittel=23uge vout $d$,

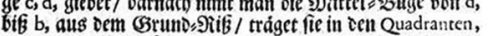

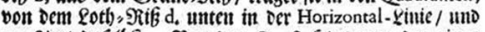
punctiret Dafelb/t. 2out oem Punet feket man icn sinen Fufi beg unverruceten Quadrant-(Sircicls/ wie aud() aus der

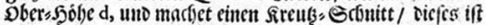

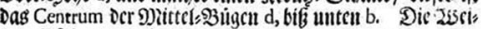
te c, bib f, uno auct) d, g wiro gicich alío aufigetragen/ unb netil diefe 3 uggen etwag forwer zu bedenten fallen/ alfo ba be tef nocf eineth Quadranten ful Dem vorigen gemacht/ $\mathrm{i} a$ mit es Deutfiefer fan ge(e)sen weroen/ uno find biejelbigen von a, bific, uno auch von a, bifi, von c, bif $f$, von $f$, bib $h$,

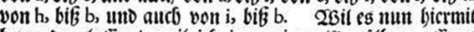
bewenten lalien / weil irf in vorigen Gewoofbern offters Deuttict) genug davon gefefricben babe.

DAS L Capitel. Die Gewölber im mittelsten Gange über dem grossen Altar. Num. III.

Derselben sind an der Zahl drei, wollen nun auch eines davon im Grund-Riß und Bock-Verstellung auffsetzen, und wird der erste Circkel des Quadranten gemacht im Grund-Ri $\beta$ von a bi $\beta$ b. Man nehme demnach die Weite von a bi $\beta$ $\mathrm{b}$, und mache einen blinden Quadranten davon. Hernach nimmt man die Weite von a bi $\beta$, träget sie von dem Loth-Ri $\beta$ des Quadranten a, und machet nach der Weite auch einen Loth-Riß c. Die Höhe nun desselben zu bekommen, behält man dieselbe Weite, und setzet einen Fu $\beta$ des Circkels oben in den Quadranten a. Und wo er im Quadrant-Circkel punctiret, von da ziehet man eine kleine Winckel-Linie biß an erwehnten Loth-Ri $\beta \mathrm{c}$, welches die Höhe des Circkels ist. Aus diesen beiden Puncten machet man nun unterhalb einen Kreuz-Schnitt, welches das Centrum der Büge a,c, ist, ferner verfähret man mit der Weite von c, bi $\beta \mathrm{d}$, träget sie von dem Lothri $\beta \mathrm{c}$, ab und machet abermahl eine Loth-Linie auffwerts. Die Höhe derselben nun zu erfahren, nimmet man im Grund-Ri $\beta$ die Weite von a, bi $\beta \mathrm{d}$, und setzet den einen Fu $\beta$ des Circkels 
oben im Quadranten a, und wo der ander Punct des Circkels bemercket wird, in dem blinden Quadranten, von da ab ziehet man eine kleine Winckel-Linie, bi $\beta$ an den vorgemachten Loth-Ri $\beta \mathrm{d}$, welches die rechte Höhe ist der Bügen $\mathrm{c}$, d. Nun mache man aus diesen beiden Puncten einen Kreuzschnitt welches Centrum die Büge $\mathrm{c}$, d giebet, darnach nimt man die Mittel-Büge von $\mathrm{d}$, bi $\beta \mathrm{b}$, aus dem Grund-Ri $\beta$, träget sie in den Quadranten, von dem Loth-Ri $\beta \mathrm{d}$, unten in der Horizontal-Linie, und punctiret daselbst. Von dem Punct setzet man den einen Fu $\beta$ des unverruckten Quadrant-Circkels, wie auch aus der Ober-Höhe $\mathrm{d}$, und machet einen Kreuz-Schnitt, dieses ist das Centrum der Mittel-Bügen $\mathrm{d}$, bi $\beta$ unten b. Die Weite c, bi $\beta \mathrm{f}$, und auch $\mathrm{d}, g$ wird gleich also auffetragen, und weil diese Bügen etwas schwer zu bedeuten fallen, also habe ich noch einen Quadranten zu dem vorigen gemacht, damit es deutlicher kan gesehen werden, und sind dieselbigen von a, bi $\beta \mathrm{e}$, und auch von a, bi $\beta \mathrm{i}$, von $\mathrm{c}$, bi $\beta \mathrm{f}$, von $\mathrm{f}$, bi $\beta \mathrm{h}$, von $\mathrm{h}$, bi $\beta \mathrm{b}$, und auch von $\mathrm{i}$, bi $\beta \mathrm{b}$. Wil es nun hiermit bewenden lassen, weil ich in vorigen Gewölbern offters deutlich genug davon geschrieben habe.

Chapter L. The vaults in the main nave over the altar. Number. III. ${ }^{2}$

These vaults are three and we want to draw their plan and elevation. We will take the first compass of the quadrant in plan from a to b. Then we take the distance ab to draw a blind quadrant. After that, we take the distance from a to $\mathrm{c}$ from the plan to the quadrant from the vertical in a to draw, according to this distance, another vertical c. To find its height, it's to maintain the same distance and to trace with it a compass in the quadrant above on a. Where both intersect, there is to trace a horizontal until the vertical line c, where it is its height defined. From these two points, it is to trace below the intersection, which will be the centre of arch ac. Then you take the distance from $\mathrm{c}$ to $\mathrm{d}$ from the plan to the vertical c to draw a new vertical. To find its height, it is to take distance from a to $d$ in plan to draw a compass with centre above in a on the quadrant. Where it marks the blind quadrant, from that point it is to trace a short horizontal line since it intersects the prior vertical $d$, which will give the correct height of arch cd. Now you trace the intersection from these both points, which will give the centre of arch cd. Then you take the arch from the plan to the quadrant from the vertical d to make a mark on the horizontal line. At this point you situate the centre of the compass of the quadrant in full size as well as from the height $\mathrm{d}$ to draw a new intersection, that will be the centre of arch $\mathrm{db}$. The distances from $\mathrm{c}$ to $\mathrm{f}$ and also from $\mathrm{d}$ to $\mathrm{g}$ are to be traced the same way, and because these arches are more difficult to draw, I have made another quadrant drawing, to make it clearer. The same procedure is from a to $\mathrm{e}$, and also from a to $\mathrm{i}$, from $\mathrm{c}$ to $\mathrm{f}$, from $\mathrm{f}$ to $\mathrm{h}$, from $\mathrm{h}$ to $\mathrm{b}$ and from $\mathrm{I}$ to $\mathrm{b}$. We

\footnotetext{
${ }^{2}$ The present transcription and its English interpretation that follows are by the author.
} 
want to stop here, because I have already described more than enough about it in the previous vaults.

There are three vaults of this kind over the altar in the main nave. To outline its plan and the elevation of its arches (Bockverstellung) you take in plan (Fig. 4) the radius ab to trace a quarter of circumference that Ranisch calls a blind-Quadrant (I would interpret "blind quadrant" as an auxiliary one). Although in the photographs of the vaults as they now exist we can see an actual rib over the diagonal, as well as on the lines connecting the contour arches, dl, while in Ranisch's drawing on plan the diagonal arch appears as a dotted line and it is called a "blind quadrant" in the text; exactly what this means is unclear.

Following the description, the next step is to transfer the distance ac from the plan to the elevation from the point a, and to trace a perpendicular to the horizontal line of the quadrant. To obtain the height of point $\mathrm{c}$, it is to be traced an arch of circumference with center in a on the elevation and radius ac, taken form the horizontal plan. From the point where this arch cuts the quadrant is to be traced a horizontal line, whose intersection with the perpendicular on $\mathrm{c}$ will give us the height of this point $\mathrm{c}$. The arch ac in the elevation traced from both points a and $\mathrm{c}$ with radius ab (Fig. 4). This procedure is not clear enough on the drawing because of the scale and the proximity of $\mathrm{c}$ to the center of the vault, but it is very clear in the written description and implies that point $\mathrm{c}$ would not be on a spherical surface.
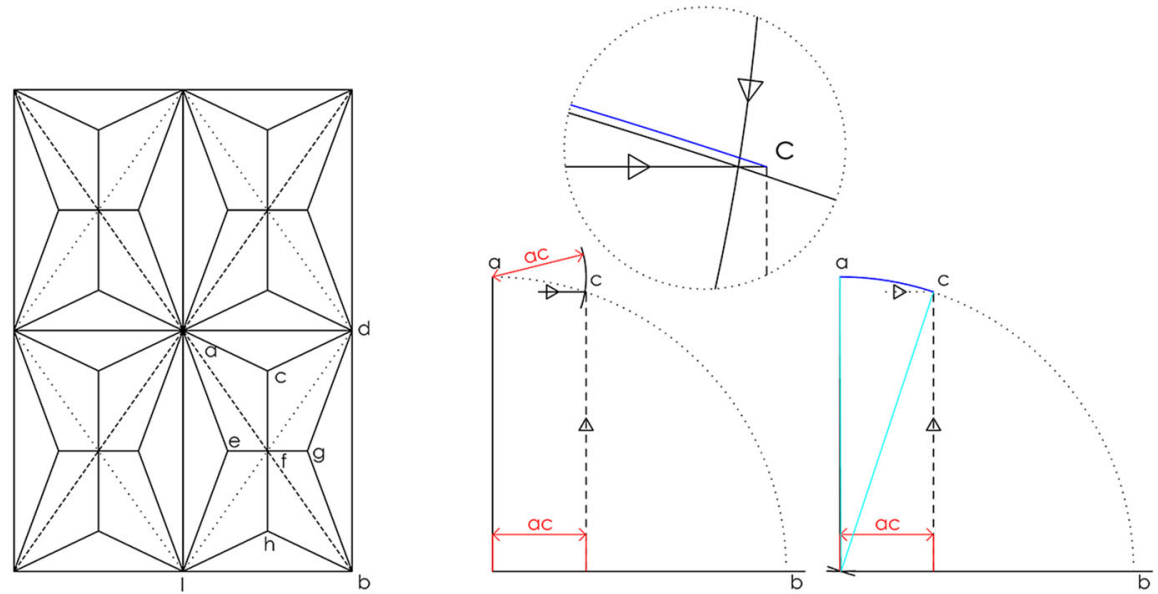

Fig. 4 Vault over the altar in St. Catarinen. Plan of the vault and elevation of arch $a c$, Prinzipalbogen in dotted line. Image: author 
Next, Ranisch describes the elevation development of arch cd (Fig. 5) following the same procedure: its length in horizontal projection is transferred from the plan to the horizontal line of the elevation, but again the height of $d$ is determined transferring its distance to the center of the vault directly to the arch of the quadrant on the elevation, as it is shown in the drawing.

To draw the elevation of arch db (Fig. 5), its length in plan is transferred to the horizontal line of the quadrant and the height of $\mathrm{b}$ is directly the baseline.

Ranisch draws the elevation of all the other arches such as cf, fb, dg, ae, ai, ei, ef, fh, hi, hb and ib, but he does not develop the written description, because the procedure is the same as before. We show in Fig. 6 two of them.

In this vault the drawing I developed on the computer is very similar to that of Ranisch (Fig. 7) and consistent with the written description. Only the length of the arch $\mathrm{fb}$ in the elevation doesn't match with the length shown in his horizontal section, which seems to be a lack of exactitude in his drawings.
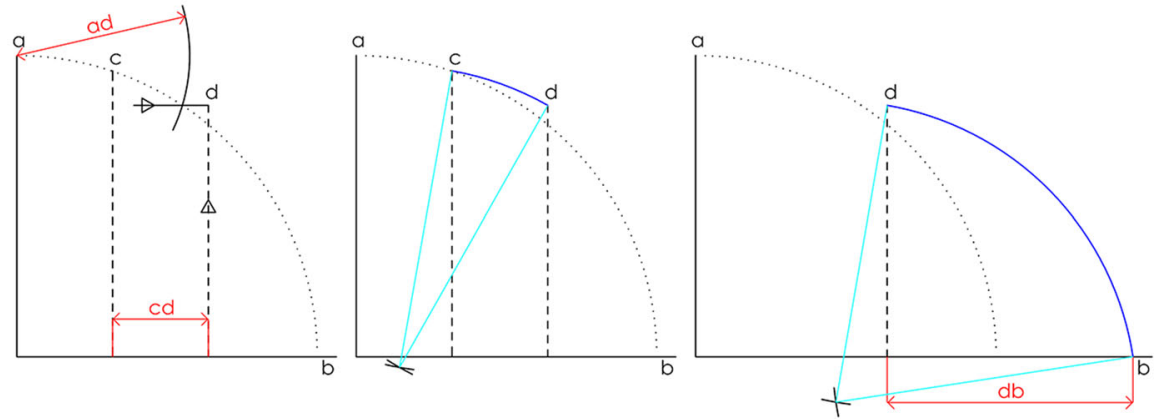

Fig. 5 Vault over the altar in St. Catarinen. Elevations of the Prinzipalbogen and arches $c d$ and $d b$. Image: author
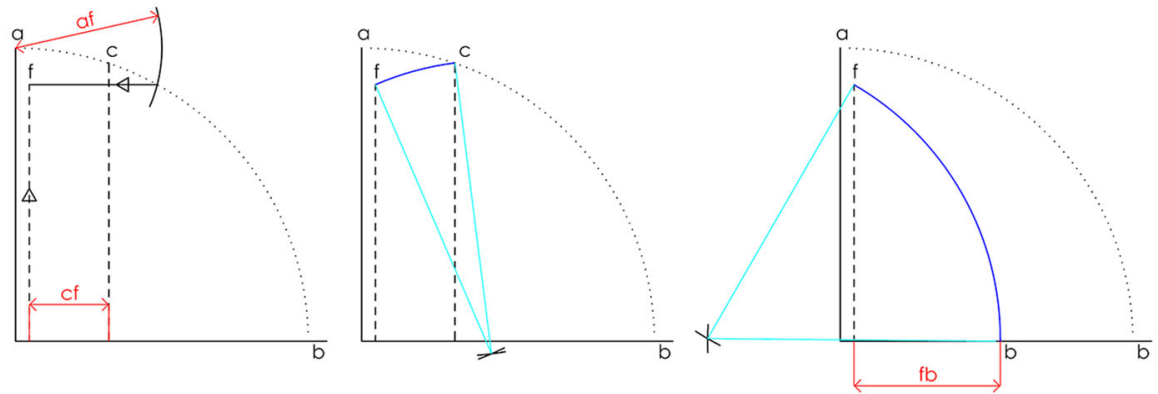

Fig. 6 Vault over the altar in St. Catarinen. Elevations of the Prinzipalbogen and arches $f c$ and $f b$. Image: author 

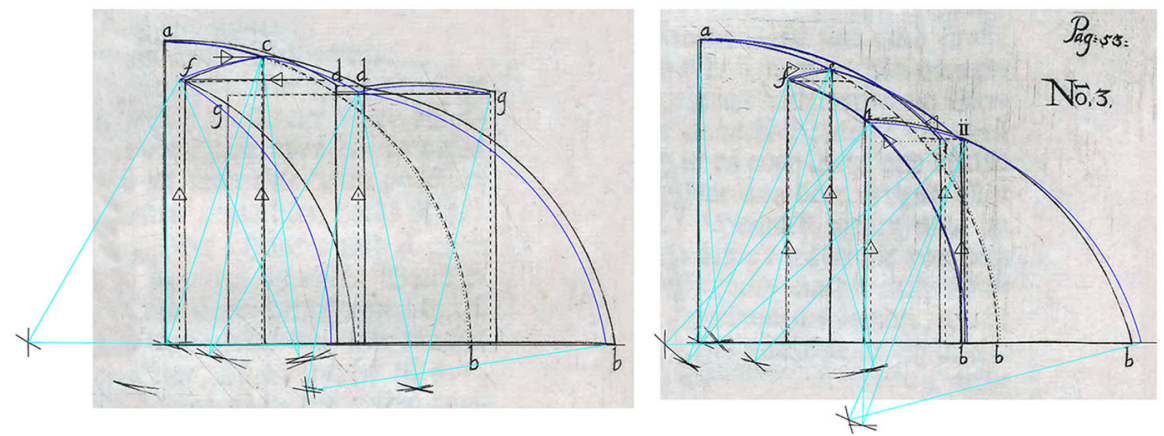

Fig. 7 Vault over the altar in St. Catarinen. Arches elevations. Superposition of the author's computer drawing over Ranisch's drawing (1695: 53)

Within this church there are four different types of vaults, shown in Fig. 8. Three of them have exposed brick ribs and one of them has not. Beside this difference, the described procedure to make the elevations of the arches is also different, but neither the description nor the drawings are in all cases clear enough. The length of the arches in horizontal projection always matches the length in plan, but the height of the intersection points is obtained by one of the following procedures:

1. The distance between the point and the center of the vault is transferred directly to the arch of the quadrant (Figs. 8 in red, 9, left);

2. The length of the arch is transferred to the horizontal base of the quadrant and projected upwards to the arch of the quadrant, what implies that the point would be situated on a theoretical spherical surface (Figs. 8 in blue, 9, centre);

3. The length of the arch is transferred directly to the quadrant (Figs. 8 in green, 9, right). 

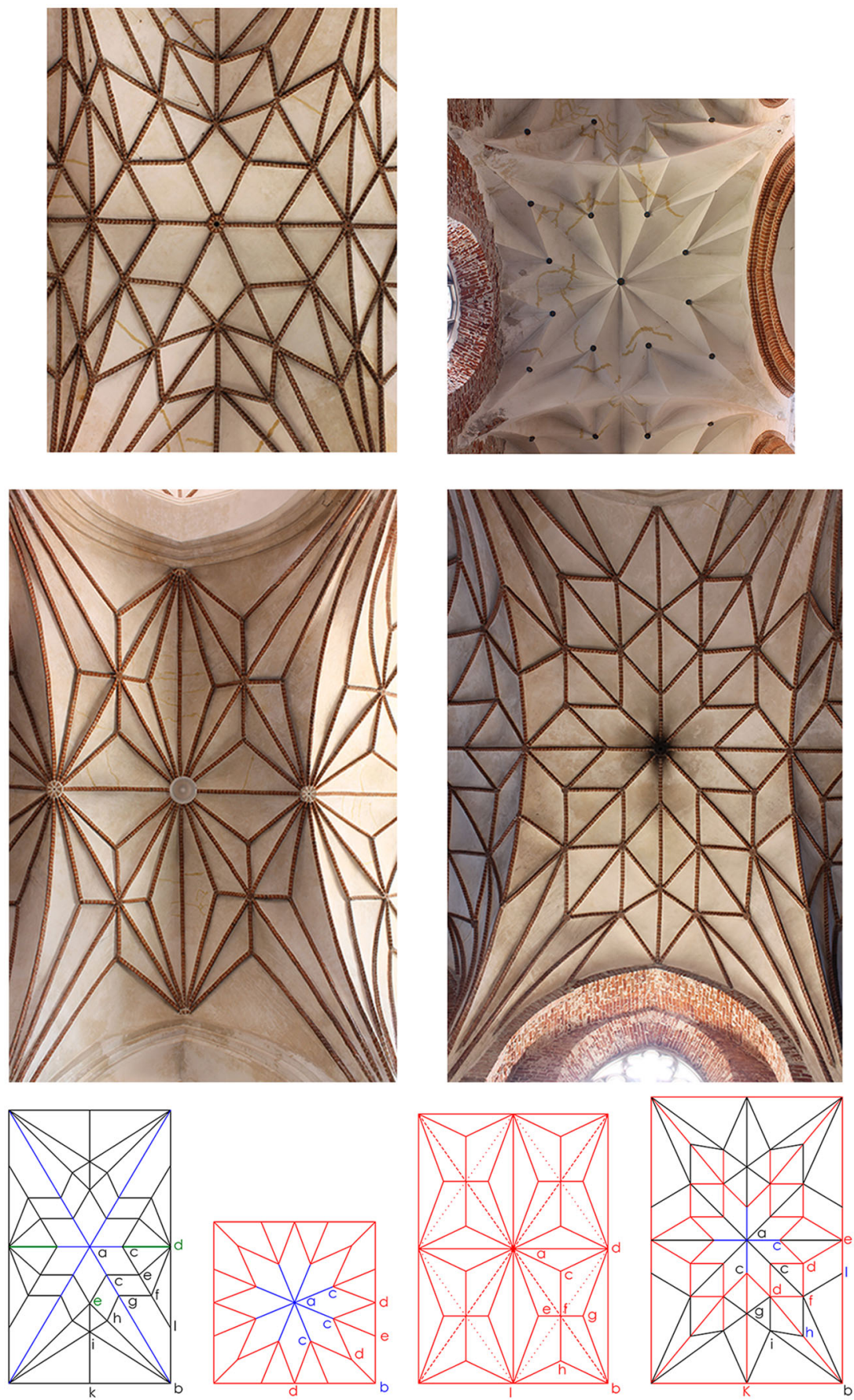

Fig. 8 Vaults in St. Catarinen. Drawings and photos: author (2014) 

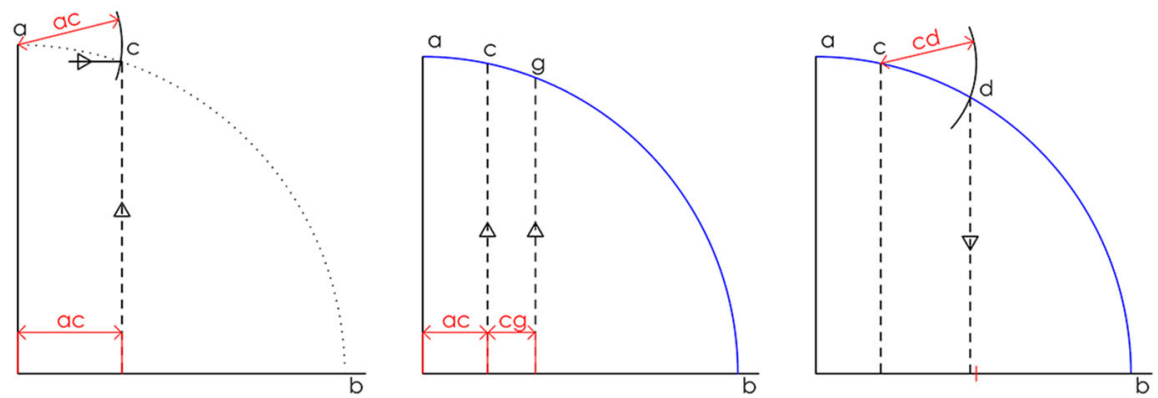

Fig. 9 Vaults in St. Catarinen. Left vault III arch $a c$; centre vault I, arch acgb; right vault I arch $c d$. Image: author

\section{The Vaults Over the Main Nave in the Convent Church of St. Trinitatis}

We can find in this church both cylindrical vaults that are mentioned by Ranisch, called Kussen-Gewölbe. Ranisch devotes a long description to this vaults because of their special feature. The procedure is nearly the same as in other vaults, except that the Prinzipalbogen is not traced over the diagonal of the vault but rather over its transversal section. The longitudinal axis is horizontal. The drawings of the plan as well as that of the elevation given by Ranisch are very similar to those developed with the aid of a computer.

We will focus on the vaults over the main nave (Fig. 10). The description of the elevation starts with the drawing of the transversal arch bk (Fig. 11). After that, the distance that will define the heights of the intersections of the arches will be the distance between them and the axis of the vault (dotted line in plan), while the length of the arches is taken in horizontal projection. So, to draw arch ac (that is, the first one), we will transfer the distance $\mathrm{c}$ to the axis directly to the arch of the elevation starting on $b$, to find the height of $c$, and then we would transfer the distance ac from the plan to the horizontal base of the elevation. In this vault, the height of all intersections is found by this procedure, and not by horizontal
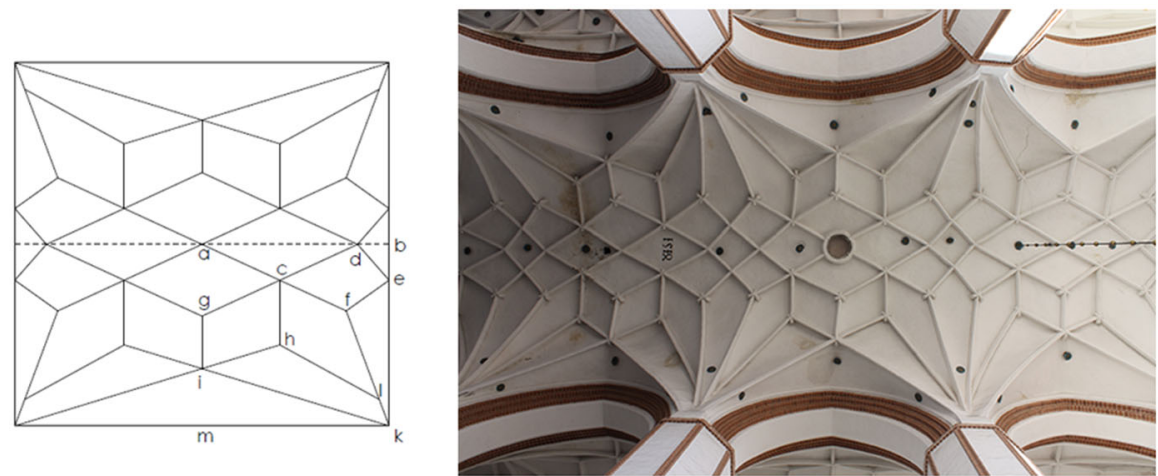

Fig. 10 Vaults over the main nave in St. Trinitatis. Image and photo: author 

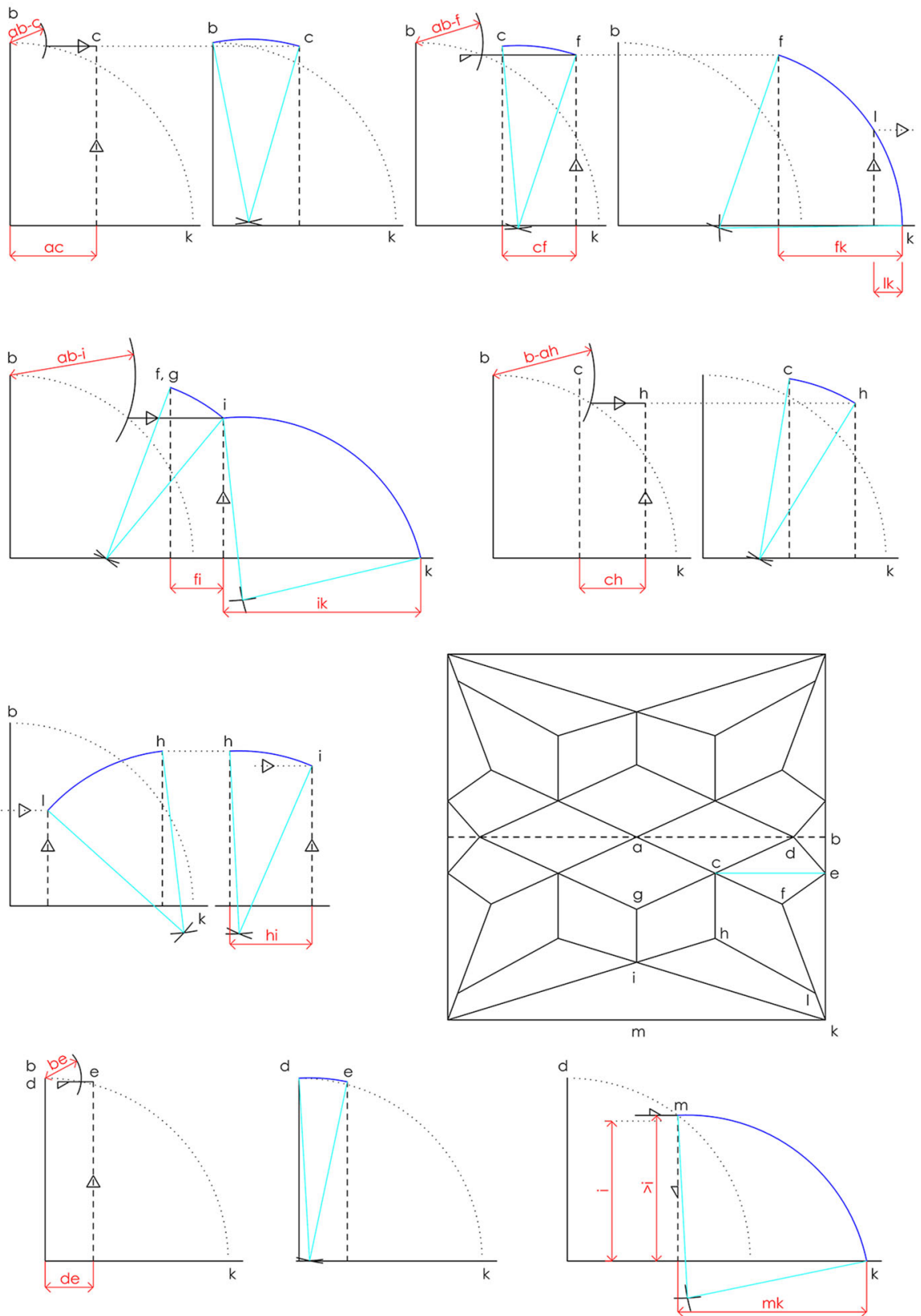

Fig. 11 Vaults in St. Trinitatis. Arches elevations. Images: author 
projection. The purpose of this image (Fig. 11) is to show the development of all the different arches of the vault in elevation, although I will not extend myself in their written description, as the procedure is the same for all of them, but I want to illustrate with this image the kind of work done by Ranisch, that may not be so clear with his drawings, where all elevations are superposed.

In Ranisch's drawing of these elevations we can find errors (Fig. 12):

- The length of both arches cg and cf is the same in elevation but not in plan or horizontal projection.

- Arch ik is very long and strange, as it is longer that the transverse arch or Prinzipalbogen; its highest point is therefore not at the end i.

- Arch hi is shown in the drawing of the elevation but is not mentioned in the written description; although it's easy to draw, it doesn't seem to be right.

With regard to point $\mathrm{m}$, the written description indicates that it should be higher that $i$, but in the elevation drawing it is situated lower that i. Further, instead of following the procedure described for contour arches in other vaults, in this case its height is decided in advance.

The description of this vault is interesting and in my opinion demonstrates the inaccuracy of the procedures described by Ranisch. He realizes that the transverse section of the vault is semicircular, but there are points that would be part of this semi-circle whose heights are not obtained by vertical projection. For example, point e, as part of arch bk, should be situated in this transverse semi-circle but following Ranisch's description it is higher than that. Moreover, Ranisch does not define the complete arch bek, but only the section be.

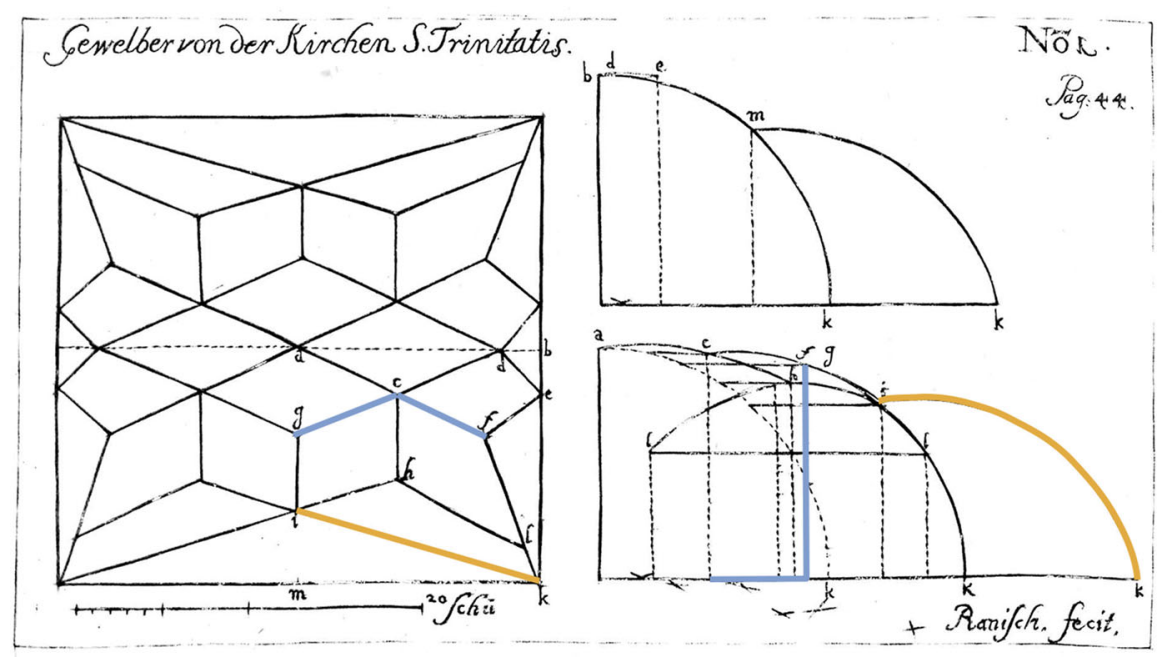

Fig. 12 Vaults over the main nave in St. Trinitatis, with errors shown. Image: (Ranisch 1695:44) 


\section{Assymetrical Vault Number V in the Dominicanerkirche}

The monastic buildings, ruined some years after the Russian bombardment of the city in 1813, were demolished around the middle of the nineteenth century. Therefore, of the seven vaults described by Ranisch, only those left the vaults inside the church remain; on the other hand, these were not damaged during World War II.

This assymetric vault, disappeared with the monastic buildings, is very similar to one in St. Catarinen church, whose description is not included in Ranisch work, although its feature is not exactly the same, because arch cd seems to have been traced over the diagonal (Fig. 13).

In this vault, the Principalbogen is traced again over the diagonal ab (Fig. 13). The height of point $\mathrm{c}$ is found by the procedure of vertical projection towards the quadrant arch, but the heights of points e and f, that are part of the contour arches, are found by the other procedure used by Ranisch that we have already explained.

Figure 14 show the page where Ranisch (1695: 33) describes vault number V in the Dominicanerkirche. Here is a transcription of that page.
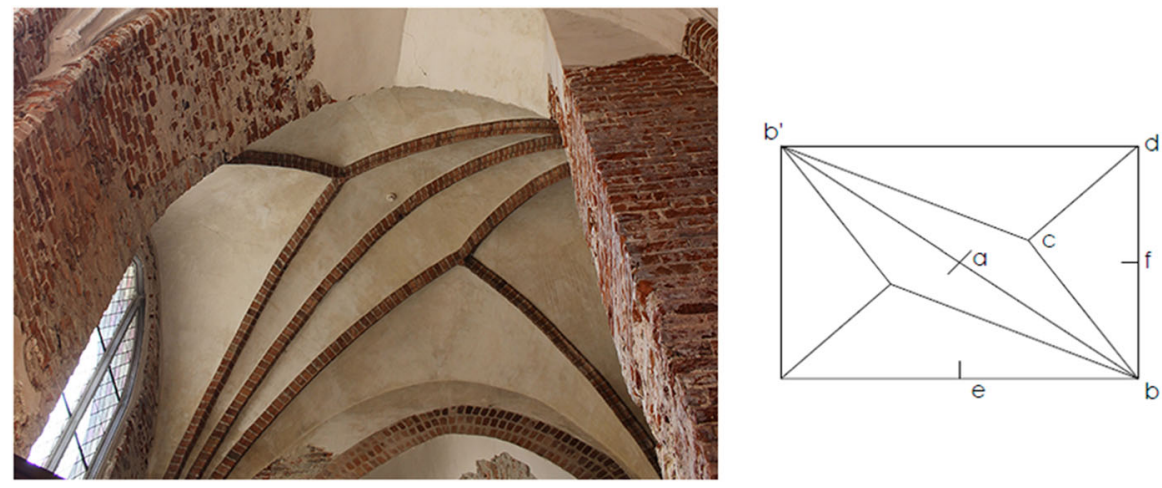

Fig. 13 Vault in St. Catarinen (photography by the author), plan of the vault in the Dominicanerkirche (drawing by Bartel Ranisch, redrawn by the author) 
Fig. 14 Description of vaults number $\mathrm{V}$ in the Dominicanerkirche by Bartel Ranisch (1695: 33)

$\frac{\text { Die vierbte Erite Deg Freuts:Ganges. }}{\text { Das XXXIV. Capitel. }}$

Num. V.

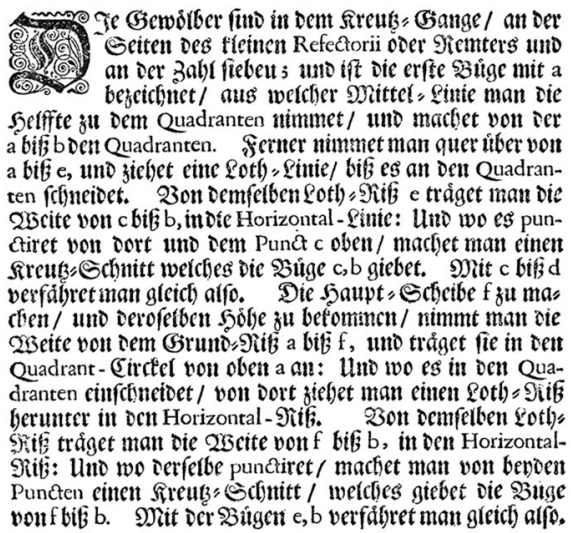

Das XXXIV Capitel. Die vierdte Seite des Kreuz-Ganges. Num. V. ${ }^{3}$

Diese Gewölber sind in dem Kreuz-Gange an der Seiten des kleinen Refectorii oder Remters und an der Zahl sieben; und ist die erste Büge mit a bezeichnet, aus welcher Mittel-Linie man die helffte zu dem Quadranten nimmet, und machet von der a bi $\beta$ b den Quadranten. Ferner nimmet man quer über von a bi $\beta \mathrm{e}$, und ziehet eine Loth-Linie bi $\beta$ es an den Quadranten schneidet. Von demselben Loth-Ri $\beta$ e träget man die Weite von $\mathrm{c}$ bi $\beta \mathrm{b}$ in die Horizontal-Linie: und wo es punctiret von dort und dem Punct c oben machet man einen Kreuz-Schnitt welches die Büge c, $\mathrm{b}$ giebet. Mit c bi $\beta \mathrm{d}$ verfähret man gleich also. Die Haupt-Scheibe f zu machen und deroselben Höhe zu bekommen nimmt man die Weite von dem Grund-Ri $\beta$ a bi $\beta \mathrm{f}$ und träget sie in den Quadrant-Circkel von oben a an: Und wo es in den Quadranten einschneidet, von dort ziehet man einen Loth-Ri $\beta$ herunter in den Horizontal-Ri $\beta$. Von demselben Loth-Ri $\beta$ träget man die Weite von $\mathrm{f}$ bi $\beta \mathrm{b}$, in den Horizontal-Ri $\beta$ : Und wo derselbe punctiret, machet man von beiden Puncten einen Kreuz-Schnitt, welches giebet die Büge von $\mathrm{f}$ bi $\beta$ b. Mit der Bügen e, b verfähret man gleich also.

Chapter XXXIV. The cloister's fourth side. Num. V.

These vaults are in the cloister near the small refectory or Remters and are seven. The first arch is designated as a, and you take the half to define the quadrant, that will be from a to b. Then you take directly the distance ae [this may be a printing error; it must be ac] and it is to trace a vertical line since it cuts the quadrant. From this vertical line c you take the distance cb to the horizontal line, and from this point and also from c above you trace both arches of circumference which intersection will give the arch cb. With cd you

\footnotetext{
3 The present transcription and its English interpretation that follows are by the author.
} 
proceed the same way. To trace the contour arch $\mathrm{f}$ [Haupt-Scheibe] and to find its height you take in plan the distance af to the quadrant from a above. From the cutting point in the quadrant it is to trace a vertical line down to the horizontal line. From this vertical you take the distance fb to the horizontal line, and from both points you trace an intersection that will give the arch $\mathrm{fb}$. With arch eb you proceed the same way.

We want to point out that there is an arch that we have called $\mathrm{cb}^{\prime}$ that Ranisch does not mention in either the text or in the elevation (Fig. 15). We have developed it in the drawing of the elevation and it results in a very domed arch, quite strange (Figs. 16 and 17).

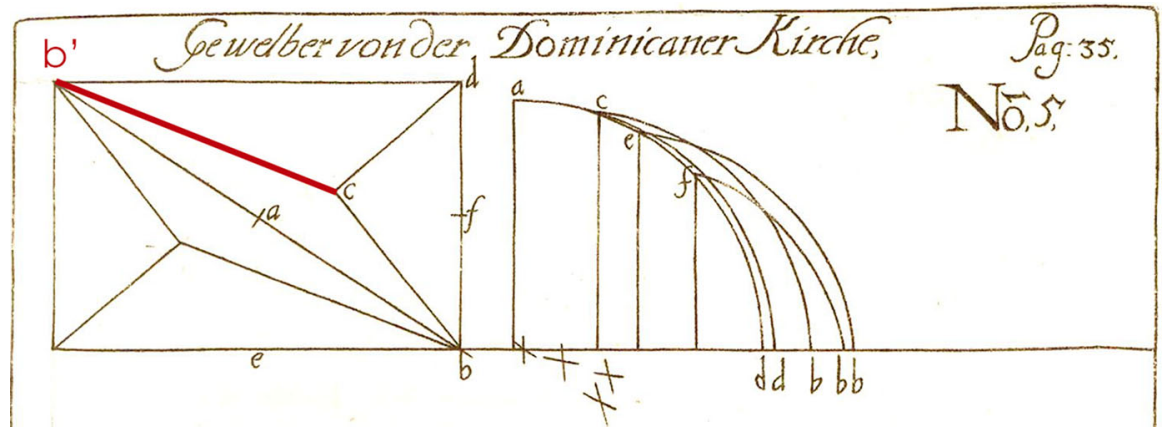

Fig. 15 Vault in the Dominicanerkirche, plan and arches elevations. Image: Ranisch (1965: 35)
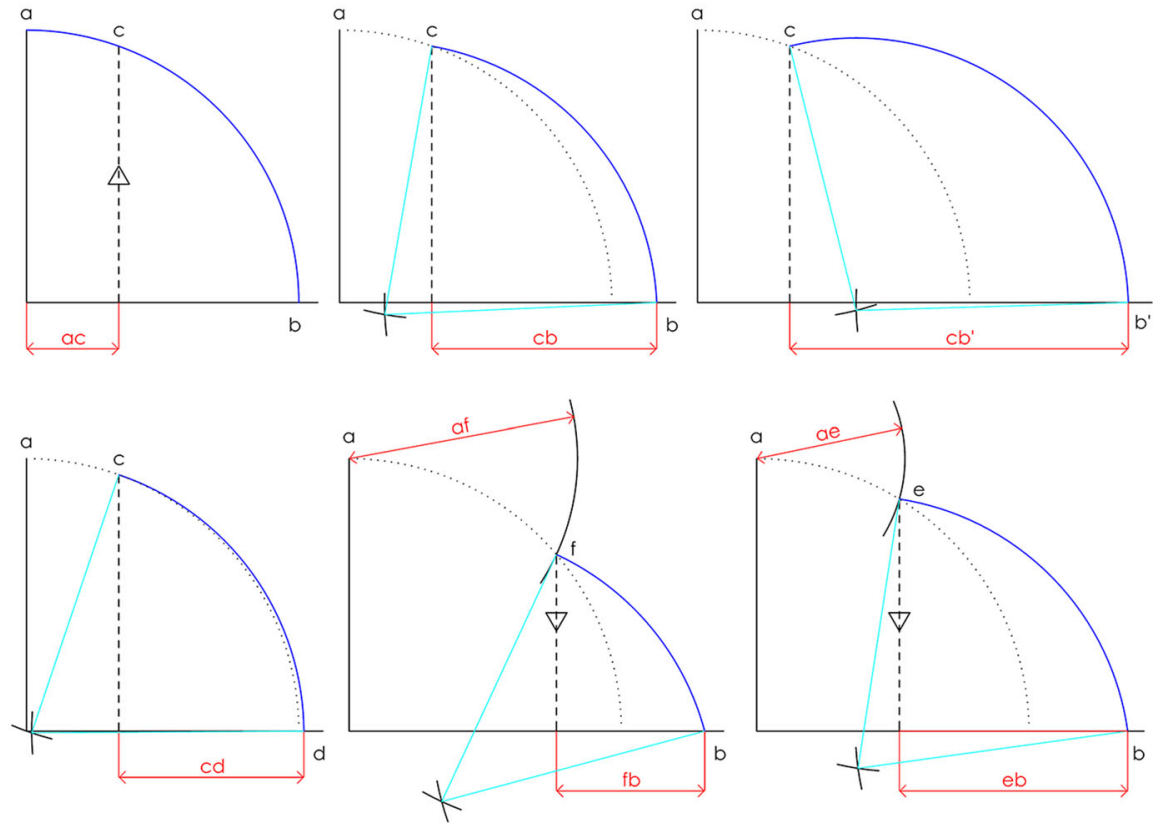

Fig. 16 Vault in the Dominicanerkirche, arches elevations. Image: author 
Fig. 17 Vault in the Dominicanerkirche, superposition of the author's computer-aided drawing and Ranisch's drawing (1695: 35)

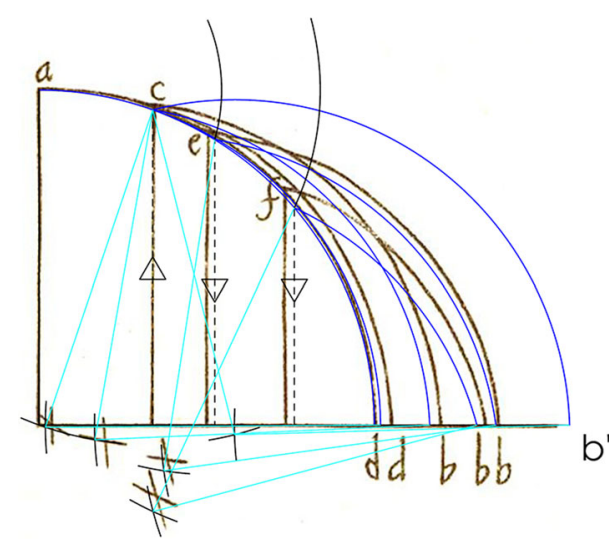

\section{Reception of Bartel Ranisch's Theory of the Prinzipalbogen}

The procedure described by Bartel Ranisch was transmitted by later authors, especially during the nineteenth century, with some differences in its interpretation. We have analyzed some authors of the nineteenth and twentieth century, such as Hoffstadt or Ungewitter, who refer to Ranisch's book, but the first thing that we want to point out is that these authors, as far as we know, focussed their attention on the first two vaults mentioned by Ranisch, which belong to Marienkirche, and that we haven't found a detailed analysis of the whole work.

Hoffstadt's chapter about the tracing of the elevation of the arches (1840-63: 168), mentions Ranisch's procedure almost literally together with the drawings of two vaults of Marienkirche in Danzig (Fig. 18). He describes vaults II and III and provides drawings that don't coincide exactly with those of Ranisch. However, in both authors we find the same mistake: the end points of the central star, called c on the drawings of both authors, are not situated at the same distance from the centre a of the vault, but in the elevations all arches ac are the same length (Fig. 18).

Hoffstadt's description of the procedure is the same as Ranisch's but not the same as that transferred later on by other authors such as Ungewitter, according to which all intersections of the arches would be situated on a theoretical sphere with a radius equal to half the diagonal of the vault.

Hoffstadt (1840-63: 168, footnote) also mentions an unpublished manuscript by Stieglitz (probably Christian Ludwig Stieglitz, Hoffstadt does not mention the title of the manuscript), which he knows through Lassaulx, referring to the tracing of Prinzipalbogen based on the largest arch traced from the springing to the center of the vault along its longest path, that is, over a fragmented path on plan. This arch would determine the rest of the arches, the height of the vault and the position of the intersections that define each group of crossing arches. This is already a change with respect to Ranisch's text.

Ungewitter describes the same procedure, based on Hoffstadt's $A B C$, but in his interpretation, he introduces something that appears to be incorrect, as he states literally that this method "is based on the fact that all intersections of the ribs would 

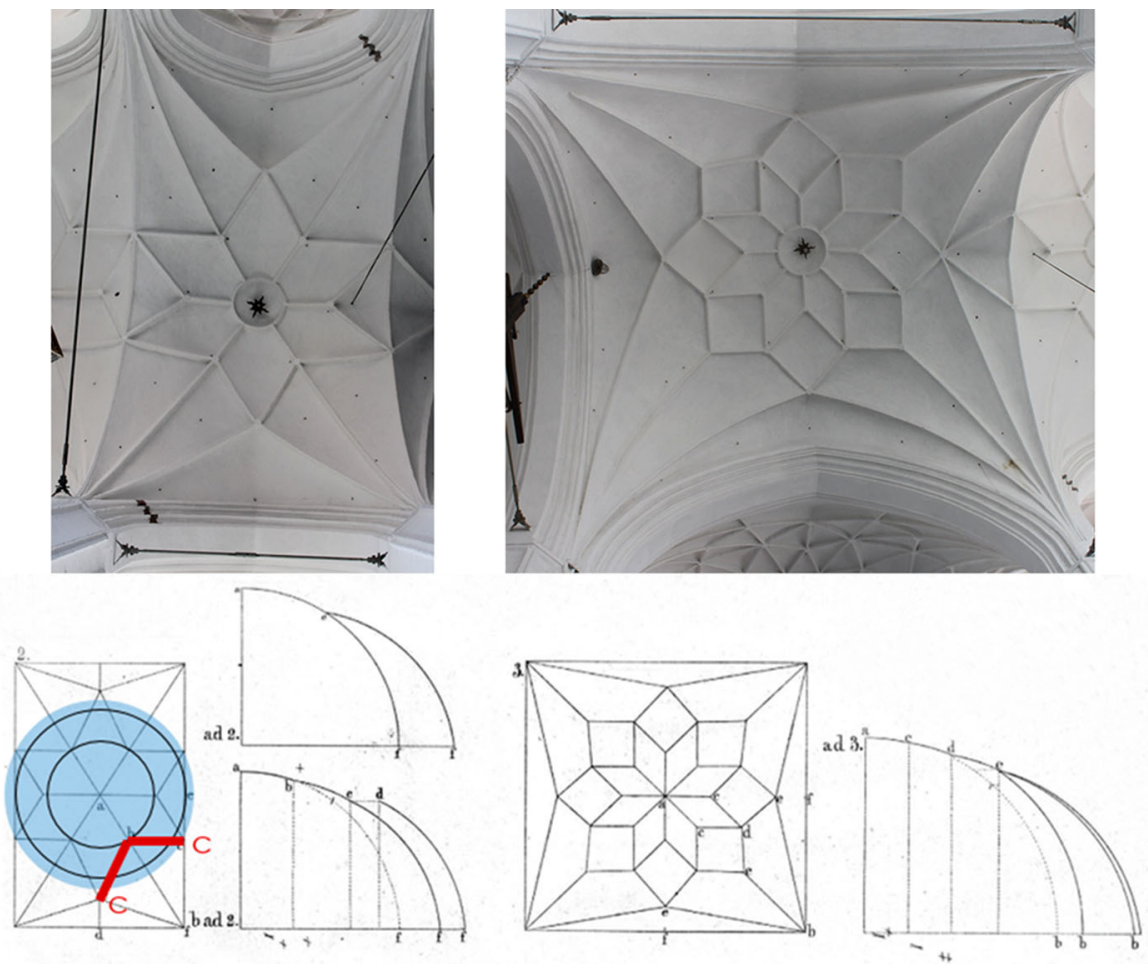

Fig. 18 Hoffstadt's ABC (1840-63: Fig. XX, plate XIVA), vaults in Marienkirche, Danzig (photographs by the author)

be situated on a spherical surface, which would determine the heights of each one from its horizontal distance to the center of the semicircular diagonal arch" (185964: 136). See Pliego $(2011,2012)$ for further details about Ungewitter's theory.

We can find later references to this procedure in other authors as Meckel (1933) and Nussbaum or Müller, but, apparently, they do not go back to the original text by Ranisch to analyze it from a purely geometrical point of view.

Following Meckel's description (Fig. 19), in a first phase of the stellar vault design, the diagonal arch, semicircular or pointed, would have determine the dimensions so that all points situated at the same distance from the center would have had the same height as the corresponding point in the diagonal rib, and its intrados would have been situated in a spherical surface.

In the development of these kind of late Gothic vaults, and according to Meckel following Ranisch's method, only the intersections of the ribs would have the height of the corresponding point on this theoretical spherical surface and the arches of the ribs would have been traced more freely with the desired radius. However, Ranisch doesn't mention any spherical surface, thus it appears that Meckel did not analyze Bartel Ranisch's publication directly but more probably relied on Ungewitter's interpretations.

Werner Müller (1977) gives us the clue of this construction history thread of Ranisch-Hoffstadt-Heideloff-Ungewitter-Meckel, pointing out that all these authors 
Fig. 19 Image: (Meckel 1933: plate 21)

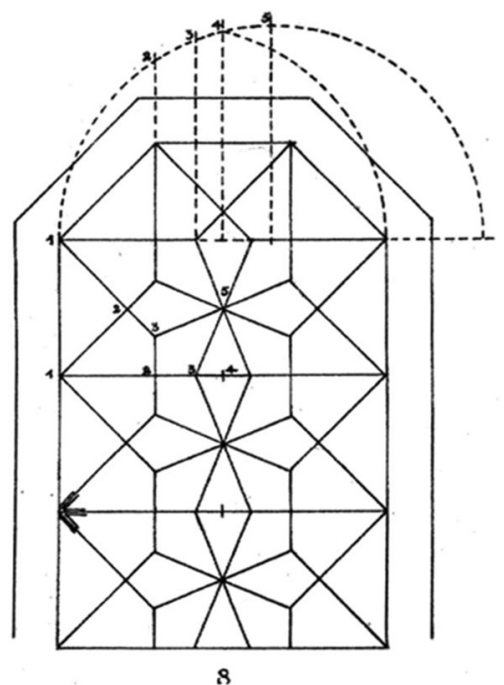

based themselves on the treatises that preceded them, and that it is not so clear how practice would have correspond to these theories. He also points out some differences in the interpretation of the Principalbogen method, but he nevertheless transfers the idea that in Ranisch's descriptions of stellar vaults all intersections of the ribs would have been situated on a sphere.

Anna Kulig and Drystyna Romaniak (2008) in "A Universal Geometrical Method for Reconstruction of Gothic Vaults" have explained Ranisch's procedure more accurately, making 3D drawings with computer technology. However, their aim did not include a study of the different interpretations of this method that had appeared in the nineteenth and twentieth centuries, nor a complete study of all vaults developed by Ranisch.

\section{Conclusions}

In Ranisch's Beschreibung aller Kirchengebäude der Stadt Dantzig we can find the germ of the concept of the Prinzipalbogen, which has been referred to repeatedly from the period of the Gothic revival to the present as the generating arch in the design of late Gothic vaults, although at the same time some doubts about its actual use in construction practice have been expressed.

Ranisch's descriptions of the tracing of the arches of late Gothic vaults and the use of an arch that he calls Haupt-Bogen or Quadrant, set out in a particular way and applied to a specific kind of vaults, present some differences from earlier treatises such as the Steinmetzbücher, where an arch that we can assimilate to the Prinzipalbogen is set out only graphically and in a different way over a broken path. Additionally, the implementation of this method based on Ranisch's descriptions does not present, from the geometrical point of view, a specific general purpose such 
as achieve a spherical surface but only a procedural method. I believe that the interpretations of Ranisch's method have simplified it and are not based on a deep analysis of the original text.

If the descriptions of Ranisch and the three procedures explained here were followed closely, the intersections of the arches would not be situated in a spherical surface but slightly higher, producing a vault that appeared groined instead of spherical. In my opinion, this could have been the reason for developing this variety of procedures applying the general method, and the small real difference between them, the reason to simplify its interpretation.

\section{References}

Curicke, Reinhold. 1686. Der Stadt Dantzig historische Beschreibung, worinnen von dero Uhrsprung Situation Regiments-Art geführten Kriegen Religions- und Kirchen-Wesen außführlich gehandelt wird. Danzig. Druck ausgegeben von Georg Reinhold Curicken.

Hoffstadt, Friedrich. 1840-63. Gothisches ABC Buch: das ist Grundregeln des gothischen Styls für Künstler und Werkleute. Frankfurt a. M.: Schmerber.

Kaplan, Helene Christine. 1974. The Danzig Churches: A Study in Late Gothic Vault Development. Ph.D. thesis, State University of New York at Binghamton.

Kulig, Anna and Krystyna Romaniak. 2008. A Universal Geometrical Method for Reconstruction of Gothic Vaults. Journal for Geometry and Graphics 12(1): 81-86.

Meckel, Carl Anton. 1933. Die Konstruktion der Figurierten Gewölbe in der deutschen Spätgotik in Architektura. Jahrbuch für Geschichte der Baukunst 1: 107-114.

Müller, Werner. 1977. Das Sterngewölbe des Lorenzer Hallenchores. Seine Stellung Innerhalb des spätgotischen Gewölbekonstruktionen. In 500 Jahre Hallenchor St. Lorenz zu Nürnberg 1477-1977. Nürnberg: Selbstverlag des Vereins für Geschichte der Stadt Nürnberg.

Nußbaum, Norbert and Sabine Lepsky. 1999. Das gotische Gewölbe. Eine Geschichte seiner Form und Konstruktion. Darmstadt: Wissenschaftliche Buchgesellschaft.

Pliego de Andrés, Elena. 2011. La geometría de las bóvedas estrelladas en el gótico tardío alemán. In: Actas del Séptimo congreso Nacional de Historia de la Construcción. Madrid: Instituto Juan de Herrera, 1147-1156.

Pliego de Andrés, Elena. 2012. Georg Gottlob Ungewitters Lehrbuch der Gotischen Constructionen. Bautechnik des Historismus. Hirmer Verlag GmbH. München.

Rabasa-Díaz, Enrique, Miguel Ángel Alonso Rodríguez and Elena Pliego de Andrés. 2015. "Trazado de bóvedas en las fuentes primarias del tardogótico: configuración tridimensional" in Actas del Noveno congreso Nacional y Primer Congreso Internacional Hispanoamericano de Historia de la Construcción. Madrid: Instituto Juan de Herrera, 1399-1408.

Ranisch, Bartel. 1695. Beschreibung aller Kirchengebäude der Stadt Dantzig. Verfasset und gezeichnet durch Bartel Ranisch. Dantzig, 1695.

Ungewitter, G. G. 1859-1864. Lehrbuch der gotischen Constructionen. Leipzig: Weige.

Elena Pliego de Andrés is a Spanish architect living and working in Madrid, Spain. She has had a professional practice since 1995. She has been teaching descriptive geometry at the School of Architecture of the Polytechnical University of Madrid (2009-2012), and is teacher since 2004 on Building Design and Construction in the vocational school IES Islas Filipinas in Madrid. She develops research works on Joseph Durm's Handbuch der Architektur, Georg Gottlob Ungewitter's Lehrbuch der gotischen Konstruktionen or Robert Willis' On the Construction of the vaults of the middle ages under the advisement of Santiago Huerta. At present, she is developing a research work about Bartel Ranisch's Beschreibung aller Kirchengebäude der Stadt Dantzig (1695) and the Prinzipalbogen procedure. 